\title{
Minireviews
}

\section{Arresting the Development of Addiction: The Role of $\beta$-Arrestin 2 in Drug Abuse}

\author{
Kirsten A. Porter-Stransky and David Weinshenker \\ Department of Human Genetics, Emory University School of Medicine, Atlanta, Georgia \\ Received February 7, 2017; accepted March 15, 2017
}

\section{ABSTRACT}

The protein $\beta$-arrestin ( $\beta$ arr) 2 directly interacts with receptors and signaling pathways that mediate the behavioral effects of drugs of abuse, making it a prime candidate for therapeutic interventions. $\beta$ arr2 drives desensitization and internalization of G protein-coupled receptors, including dopamine, opioid, and cannabinoid receptors, and it can also trigger $\mathrm{G}$ protein-independent intracellular signaling. $\beta$ arr2 mediates several drug-induced behaviors, but the relationship is complex and dependent on the type of behavior (e.g., psychomotor versus reward), the class of drug (e.g., psychostimulant versus opioid), and the circuit being interrogated (e.g., brain region, cell type, and specific receptor ligand). Here we discuss the current state of research concerning the contribution of $\beta$ arr2 to the psychomotor and rewarding effects of addictive drugs. Next we identify key knowledge gaps and suggest new tools and approaches needed to further elucidate the neuroanatomical substrates and neurobiological mechanisms to explain how $\beta$ arr2 modulates behavioral responses to drugs of abuse, as well as its potential as a therapeutic target.

\section{Introduction}

G protein-coupled receptors (GPCRs) mediate many of the neurochemical and behavioral effects of addictive drugs. For example, most drugs of abuse increase dopamine neurotransmission in the mammalian brain, either directly or indirectly, which leads to the stimulation of dopaminergic GPCRs (Di Chiara and Imperato, 1988; Lüscher and Ungless, 2006; Pierce and Kumaresan, 2006). Some classes of drugs, such as opioids and cannabinoids, are agonists at opioid and cannabinoid receptors, respectively, which are also GPCRs. GPCR signaling is thus a critical component of drug-induced neurotransmission.

Termination of signal transduction at GPCRs is necessary to prevent continual signaling and to allow receptors to be reactivated by ligands. Arrestins, which were first discovered in photoreceptor-expressing cells in the eye (Dolph, 2002), are proteins that bind to active phosphorylated GPCRs and

This research was supported by the National Institutes of Health National Institute on Drug Abuse [R01 DA038453 (to D.W.)] and the National Institutes of Health National Institute of Neurological Disorders and Stroke [F32 NS098615 (to K.A.P.-S.)]

https://doi.org/10.1124/jpet.117.240622. inactivate them (Gurevich and Gurevich, 2004). Visual arrestins are located primarily in the eye, and nonvisual arrestins, also known as $\beta$-arrestins ( $\beta$ arrs), are ubiquitously expressed. $\beta$ arrs, so named from the discovery of their interactions with $\beta$-adrenergic receptors (Attramadal et al., 1992), are scaffolding proteins involved in the desensitization and internalization of GPCRs at the plasma membrane. They can also initiate intracellular signaling cascades independent of canonical $\mathrm{G}$ protein signaling (Smith and Rajagopal, 2016). GPCRs in the membrane were thought to signal until $\beta$ arr desensitized and internalized them; however, recent experiments have shown that certain GPCRs can signal after being internalized by $\beta$ arr into endosomes (Irannejad et al., 2013), and $\beta$ arr can even potentiate Gs signaling (Wehbi et al., 2013). $\beta$ arrs can interact with extracellular signal-regulated kinase (ERK), Protein kinase B, mitogenactivated protein kinase kinase, Raf-1, c-Jun N-terminal kinase, and ubiquitin ligases, to name a few (Luttrell et al., 2001; Shenoy et al., 2001; Beaulieu et al., 2005; Del'guidice et al., 2011; Urs et al., 2011; Kuhar et al., 2015). $\beta$ arr can also modulate nuclear factor- $\kappa \mathrm{B}$ through $\mathrm{I} \kappa \mathrm{B} \alpha$ (Gao et al., 2004). Additional interactions and complexities of $\beta$ arr continue to be discovered; therefore, the field's understanding of $\beta$ arr is constantly evolving.

ABBREVIATIONS: 5-HT, serotonin; $\beta$ arr, $\beta$-arrestin; CP55940, (-)-cis-3-[2-hydroxy-4-(1,1-dimethylheptyl)phenyl]-trans-4-(3-hydroxypropyl)cyclohexanol; CPP, conditioned place preference; DAMGO, (2S)-2-[[2-[[(2R)-2-[[(2S)-2-amino-3-(4-hydroxyphenyl)propanoyl]amino]propanoyl]amino]acetyl]methylamino]- $N$-(2-hydroxyethyl)-3-phenylpropanamide; DREADD, designer receptors exclusively activated by designer drugs; ERK, extracellular signal-regulated kinase; GPCR, G protein-coupled receptor; JNK, c-Jun N-terminal-activated protein kinase kinase; JWH-073, (1-butyl-1H-indol-3-yl)1-naphthalenyl-methanone; KO, knockout; LSD, lysergic acid diethylamide; MEK, mitogen-activated protein kinase kinase; MSN, medium spiny neuron; O-1812, (5Z,8Z,11Z,14Z)-20-cyano- $N$-[(2R)-1-hydroxypropan-2-yl]-16,16-dimethylicosa-5,8,11,14-tetraenamide; PCP, phencyclidine; PZM21, 1[(2S)-2-(dimethylamino)-3-(4-hydroxyphenyl)propyl]-3-[(2S)-1-(thiophen-3-yl)propan-2-yl]urea; SNP, single nucleotide polymorphism; UNC9994 (5-\{3[4-(2,3-dichlorophenyl)piperidin-1-yl]propoxy\}-1,3-benzothiazole. 
Functional selectivity, also known as biased agonism, is the principle that agonists bound to a GPCR can preferentially signal through different pathways. GPCR ligands can selectively activate intracellular $G$ protein signaling, $\beta$ arr pathways, or both to varying degrees (Luttrell et al., 2015). Biased agonism complicates GPCR activity, as different agonists at the same receptor can have opposing effects on physiology (Boerrigter et al., 2012; Tarigopula et al., 2015). Ligands that preferentially engage $\beta$ arr versus G protein signaling can alter responses to opioids, psychostimulants, and hallucinogens (Soergel et al., 2014; Peterson et al., 2015; Manglik et al., 2016; Urs et al., 2016); therefore, biased agonists could be potential therapeutics for addiction, analgesia, and other conditions.

There are two $\beta$ arrs: $\beta$-arrestin 1 ( $\beta$ arr1; also known as arrestin-2) and $\beta$-arrestin 2 ( $\beta$ arr2, also known as arrestin-3). $\beta$ arr1 and $\beta$ arr2 can have similar or distinct roles in cells, and their function can vary by cell type. For example, reduction of either $\beta$ arr1 or $\beta$ arr2 decreased $\beta 2$-adrenergic induced ERK signaling (Shenoy et al., 2006). However, angiotensin II receptor-mediated ERK signaling decreased with a reduction of $\beta$ arr2 but increased with downregulation of $\beta$ arr1 (Ahn et al., 2004). Most class A receptors (including dopamine, opioid, and cannabinoid receptors) bind both $\beta$ arr1 and $\beta$ arr2; however, they have a higher affinity for $\beta$ arr2 (Oakley et al., 2000 ), making $\beta$ arr2 a likely candidate for modulating GPCR signaling and the effects of drugs of abuse.

Indeed, mice lacking $\beta$ arr2 but not $\beta$ arr1 have altered behavioral responses to addictive drugs, including morphine (Bohn et al., 2003; Urs and Caron, 2014), amphetamine (Urs and Caron, 2014), and alcohol (Li et al., 2013) (Table 1); therefore, $\beta$ arr2 is a likely candidate for modulating the effects of drugs of abuse. The purpose of this review is to catalog what is currently known about the role of $\beta$ arr2 in mediating the behavioral effects of various drugs of abuse and to discuss the questions that remain and what techniques are needed to properly answer these questions. For a more thorough review of the cellular and molecular functions of $\beta$ arr2, we refer the reader to Smith and Rajagopal (2016).

\section{Barr2 Modulates the Effects of Multiples Classes of Drugs of Abuse}

Opioids. Most of the pioneering studies that examined the role of $\beta$ arr2 in the behavioral effects of drugs of abuse used conventional $\beta$ arr2 knockout (KO) mice, which completely lack $\beta$ arr2 in all cells throughout development and in adulthood. $\beta$ arr2-KO mice have significantly blunted morphine-induced locomotion but enhanced morphine reward, as measured by conditioned place preference (CPP) (Bohn et al., 2003).
Because many psychomotor drug effects are mediated by dopamine neurotransmission in the striatum and prefrontal cortex (Pierce and Kumaresan, 2006), $\beta$ arr2 is presumed to exert its effects in the mesocorticolimbic system. Indeed, Barr2-KO mice exhibit higher morphine-induced dopamine release in the striatum compared with controls (Bohn et al., 2003). $\beta$ arr2 in medium spiny neurons (MSNs) that contain dopamine receptors in the dorsal and ventral striatum may also modulate the psychomotor effects of drugs. However, the relative contribution of the D1 or D2 family of dopamine receptors to the differing drug-induced behavioral effects is unknown. Determining which family of dopamine receptors mediates such effects is important because D1 and D2 receptors have opposing influences on the excitability of MSNs (Beaulieu and Gainetdinov, 2011) and are anatomically segregated onto separate populations of MSNs that project to different brain regions (Lobo and Nestler, 2011). Indeed, activation of D1- versus D2-containing MSNs causes differential changes in whole-brain activity (Lee et al., 2016) and has opposite effects on reinforcement (Kravitz et al., 2012).

$\beta$ arr2 in D1-containing neurons was initially proposed as a mechanism for morphine-induced locomotion. In support of this hypothesis, morphine normally induces a $\beta$ arr2/pERK signaling complex, but this did not occur in D1-KO mice (Urs et al., 2011). In addition, D1-KO mice and wild-type animals developed a similar CPP for morphine (Urs et al., 2011), demonstrating that $\mathrm{D} 1$ receptors are not necessary for morphine reward. To directly test the role of $\beta$ arr2 in D1containing neurons, morphine CPP and locomotion could be tested in conditional KO mice that lack $\beta$ arr2 only in D1containing cells (Urs et al., 2016). Similarly, future experiments should directly test the role of $\beta$ arr2 in D2-containing neurons in mediating the effects of morphine.

While $\beta$ arr2's interactions with dopamine receptors may modulate opioid effects, $\mu$-opioid receptor recruitment of $\beta$ arr2 could also be important because morphine has a high affinity for $\mu$-opioid receptors, which, like dopamine receptors, are expressed on striatal MSNs, among other regions. Historically, however, morphine was found to not recruit $\beta$ arr2 and prompt the internalization of $\mu$-opioid receptors as readily as many other $\mu$-opioid receptor agonists. For example, etorphine caused robust internalization of $\mu$-opioid receptors in the cortex of rats 30 minutes postadministration, whereas morphine caused no detectable $\mu$-opioid receptor endocytosis (Keith et al., 1998). Similarly, previous in vitro experiments did not find morphine-induced recruitment of $\beta$ arr2 or the internalization of $\mu$-opioid receptors in human embryonic kidney cells; unless GPCR kinase was overexpressed (Zhang et al., 1998), $\beta$ arr was overexpressed, or $\beta$ arr1 was eliminated and only $\beta$ arr2 was available (Whistler and von Zastrow, 1998). However, morphine did trigger the rapid endocytosis of $\mu$-opioid receptors in striatal neurons (Haberstock-Debic

TABLE 1

The behavioral effects of drugs of abuse in mice completely lacking $\beta$ arr2

\begin{tabular}{llll}
\hline \multicolumn{1}{c}{ Drug } & \multicolumn{1}{c}{ Drug-Induced Locomotion } & \multicolumn{1}{c}{ Locomotor Sensitization } & CPP \\
\hline Cocaine & Similar to controls & Currently unknown & Similar to controls \\
Amphetamine & Blunted compared with controls & Currently unknown & Currently unknown \\
Morphine & Blunted compared with controls & Similar to controls & Enhanced compared with controls \\
Alcohol & Blunted compared with controls & Currently unknown & Enhanced compared with controls \\
Nicotine & Similar to controls; blunted compared with controls & Blunted compared with controls & Currently unknown \\
Cannabinoids & Currently unknown & Currently unknown & Currently unknown \\
\hline
\end{tabular}


et al., 2005). Despite morphine's reduced ability to recruit $\beta$ arr2 in some cells, $\beta$ arr2 is critical for morphine's effects. In vitro experiments using $\beta$ arr2-KO, $\beta$ arr1-KO, and control cells revealed that, unlike the selective $\mu$-opioid receptor agonist DAMGO [(2S)-2-[[2-[[(2R)-2-[[(2S)-2-amino-3-(4-hydroxyphenyl)propanoyl]amino]propanoyl]amino] acetyl]-methylamino]- $N$ (2-hydroxyethyl)-3-phenylpropanamide], which can recruit either $\beta$ arr 1 or $\beta$ arr 2 to $\mu$-opioid receptors, morphine appears to be able to recruit only $\beta$ arr2. Indeed, $\beta$ arr2 but not $\beta$ arr1 internalized morphine-activated $\mu$-opioid receptors (Groer et al., 2011). Together, these studies indicate that $\mu$-opioid receptors recruit $\beta$ arr2 in certain cell populations, such as MSNs, but not in others, and sensitive assays are needed to observe these effects. Furthermore, different opioids can elicit unique adaptations that alter how $\beta$ arr2 is engaged and highlight the importance of biased agonism in understanding $\beta$ arr 2 recruitment.

The ability or inability of $\mu$-opioid agonists to recruit $\beta$ arr2 can have important behavioral consequences. The $\mu$-opioid receptor agonists morphine, heroin, and oxycodone have low recruitment of $\beta$ arr 2 and low levels of endocytosis (Keith et al., 1998; Whistler and von Zastrow, 1998; Zhang et al., 1998); however, all three have high abuse potential and can cause tolerance and dependence. It has therefore been hypothesized that the lack of opioid-induced desensitization and internalization of $\mu$-opioid receptors contributes to these features of addiction. To test this hypothesis, a mutant recycling $\mu$-opioid receptor that desensitizes and internalizes in response to morphine was created (Finn and Whistler, 2001). Interestingly, although these mice had an enhanced CPP to low doses of morphine, they neither escalated morphine consumption nor exhibited aberrant motivation for drug over weeks of morphine self-administration, unlike wild-type mice, which escalated intake, continued to self-administer drug despite the threat of footshock, and had greater reinstatement of drug seeking (Berger and Whistler, 2011). These results demonstrated that $\mu$-opioid receptor internalization has different effects on drug reward (as measured by CPP) versus the development of more complex addictive-like behaviors. Because $\beta$ arr2 is recruited to morphine-activated receptors to internalize them (Groer et al., 2011), it may play an important role in preventing the transition from recreational use to addiction. Future experiments should investigate this directly.

To determine how endogenous $\beta$ arr2 changes with morphine exposure, in situ hybridization was conducted on the brains of rats with a history of morphine administration. Chronic but not acute morphine exposure increased $\beta$ arr2 mRNA in the cortex and decreased $\beta$ arr2 mRNA in the periaqueductal gray (Fan et al., 2003). In addition, naloxoneprecipitated withdrawal robustly increased $\beta$ arr2 mRNA in the hippocampus (Fan et al., 2003). These experiments revealed that $\beta$ arr2 can be differentially regulated in various brain regions in response to drugs. Future experiments are needed to determine the behavioral and biologic effects of changing $\beta$ arr2 levels in these and other brain regions.

Consistent with the animal research indicating that $\beta$ arr2 modulates drug effects, human studies have found differences in $\beta$ arr2 in people susceptible to opioid abuse. Indeed, individuals who died from heroin overdose had decreased levels of $\beta$ arr 2 specifically in the prefrontal cortex compared with matched controls (Ferrer-Alcón et al., 2004). In addition, a haplotype block that spans the $\beta$ arr2 locus has been discovered, and four single nucleotide polymorphisms (SNPs) (rs34230287, rs3786047, rs1045280, and rs2036657) have been studied in opioid-dependent humans under treatment. Those who were homozygous for the variant allele of any three of the four SNPs (all but rs34230287) were more likely to continue using opioids or cocaine while on methadone maintenance treatment (Oneda et al., 2011). This demonstrated that genetic differences in $\beta$ arr 2 can confer resistance to methadone treatment of opioid dependence. None of these SNPs cause changes in the amino acid sequence, and the biologic effects of each are not yet known; however, different SNPs could reduce, enhance, or have no effect on GPCRs and $\beta$ arr2 signaling. Future research should investigate the physiologic effects of each of these SNPs and whether they cause changes in $\beta$ arr 2 expression in different brain regions.

Chronic pain is a common reason why individuals begin taking opioids, which can transition into opioid addiction; therefore, examining the role of $\beta$ arr2 in opioid modulation of pain is an important consideration. Paradoxically, $\mu$-opioid receptor agonists that readily recruit $\beta$ arr2, such as fentanyl, methadone, and etorphine, caused similar analgesia in wildtype and $\beta$ arr2-KO mice; however, agonists that do not robustly recruit $\beta$ arr2, such as morphine and heroin, enhanced analgesia in $\beta$ arr2-KOs compared with controls (Bohn et al., 1999, 2004a). Similarly, both wild-type and $\beta$ arr2-KO mice developed tolerance to fentanyl, oxycodone, and methadone (Raehal and Bohn, 2011) but not to morphine after chronic administration (Bohn et al., 2002; Raehal and Bohn, 2011). Although $\beta$ arr2 is not readily recruited by morphine in all cell types, it can play a critical role in desensitizing $\mu$-opioid receptors (Bohn et al., 2002, 2004a; Groer et al., 2011).

Barr2 likely mediates many of morphine's negative side effects. In support of this idea, $\beta$ arr2-KO mice have significantly reduced morphine-induced constipation and respiratory suppression, compared with controls (Raehal et al., 2005). In addition, after screening over 3 million molecules as new potential opioids, the compound PZM21 (1-[(2S)-2-(dimethylamino)-3-(4-hydroxyphenyl)propyl]-3-[(2S)-1-(thiophen-3-yl)propan-2-yl]urea) was found to have high selectivity for the $\mu$-opioid receptor and to strongly activate $\mathrm{Gi}$ signaling without engaging $\beta$ arr2 (Manglik et al., 2016). Interestingly, PZM21 was an effective analgesic in the hotplate test (which engages brain and spinal pain circuits) but not in the tail-flick test (which solely engages spinal, reflexive circuits), suggesting that this novel opioid causes affective but not reflexive analgesia. Unlike morphine, which has high abuse potential, doses of PZM21 that cause analgesia did not increase locomotor active or support a CPP. Combined, these experiments demonstrate that $\mu$-opioid receptor agonists that preferentially engage $\mathrm{Gi}$, but not $\beta$ arr2, signaling could be effective treatments for pain without the negative side effects and high abuse potential.

For a more comprehensive review of $\beta$ arr2's involvement in opioid-mediated analgesia, please refer to Raehal and Bohn (2014). Because $\beta$ arr2 is differentially involved in the antinociceptive effects of various opioids, future experiments should test the role of $\beta$ arr2 in the rewarding effects of opioids other than morphine. In addition, functionally selective agonists such as PZM21 could be used in future experiments to preferentially engage $\mathrm{Gi}$ signaling after $\mu$-opioid receptor activation. 
Cannabinoids. As with morphine, cannabinoid receptor agonists can provide pain relief and are abused. Both CB1 and CB2 cannabinoid receptors recruit $\beta$ arr2 (McGuinness et al., 2009; van der Lee et al., 2009; Turu and Hunyady, 2010; Delgado-Peraza et al., 2016). Most research has focused on CB1 (Daigle et al., 2008; Mahavadi et al., 2014; DelgadoPeraza et al., 2016), whereas very little is known about the potential contribution of $\beta$ arr2 to the effects of CB2 activation (Atwood et al., 2012). $\beta$ arr2 is involved in the behavioral effects of some but not all cannabinoid receptor agonists (Raehal and Bohn, 2014). The cannabinoid receptor agonist $\Delta^{9}$-tetrahydrocannabinoid caused greater antinociception in $\beta$ arr2-KO mice compared with controls (Breivogel et al., 2008; Nguyen et al., 2012), but no differences between genotypes were observed for the CB1 agonists CP55940 [(-)-cis-3-[2-hydroxy-4-(1,1dimethylheptyl)phenyl]-trans-4-(3-hydroxypropyl)cyclohexanol], methanandamide, JWH-073 [(1-butyl-1H-indol-3-yl)-1naphthalenyl-methanone], and O-1812 [(5Z,8Z,11Z,14Z)20-cyano- $N$-[(2R)-1-hydroxypropan-2-yl]-16,16-dimethylicosa-5, 8,11,14-tetraenamide] (Breivogel et al., 2008). Seven-day treatment with CP55940 increased $\beta$ arr2 mRNA and protein levels in the prefrontal cortex (Franklin et al., 2013), suggesting that cannabinoid agonists can upregulate $\beta$ arr2.

To our knowledge, the role of $\beta$ arr2 in the rewarding effects of cannabinoids has yet to be examined. Because of the growing use and legalization of marijuana, future experiments should examine the role of $\beta$ arr2 in modulating cannabinoid reinforcement and use.

Psychostimulants. The first published experiments examining the role of $\beta$ arr2 in behavioral responses to psychostimulants were conducted using $\beta$ arr2-KO mice. No robust differences in cocaine-induced locomotion, locomotor sensitization to cocaine, or cocaine CPP were documented in $\beta$ arr2-KO mice compared with wild-type controls (Bohn et al., 2003). $\beta$ arr2-KO mice appeared to have slightly reduced cocaine-induced locomotion; yet this is difficult to interpret, given baseline differences in locomotor activity between genotypes (Bohn et al., 2003, 2004b). However, $\beta$ arr2-KO mice had significantly blunted amphetamine-induced locomotion, and this effect was not due to differences in stereotypy (Beaulieu et al., 2005). Similarly, mice lacking $\beta$ arr2 in all neurons (generated by crossing floxed $\beta$ arr2 mice with cytomegalovirusCre mice) showed impaired amphetamine-induced locomotion compared with controls (Urs et al., 2016). There are a few possible explanations as to why differences in locomotion were observed after amphetamine but not cocaine in mice lacking $\beta$ arr2. If $\beta$ arr2 deletion had a real but more subtle effect on cocaine-induced locomotion than amphetamine-induced locomotion, collapsing the data and analyzing 90-minute time bins could obscure the effect. In addition, it is possible that $\beta$ arr 1 compensates in the absence of $\beta$ arr2 to facilitate cocaine- but not amphetamine-induced locomotion. Given the different ways that cocaine and amphetamine interact with the dopamine transporter (reuptake blocker versus substrate/releaser, respectively) and the regulation of dopamine transporter function by intracellular signaling (Schmitt and Reith, 2010), it is plausible that $\beta$ arr2 interacts either directly or indirectly with the dopamine transporter in such a way that cocaine and amphetamine are differentially affected, although we are not aware of data to substantiate this explanation.

As detailed in the opioid section, determining whether $\beta$ arr2 influences drug effects via D1- or D2-containing neurons is important due to these receptors' opposing effects and projections to different brain regions. Eliminating $\beta$ arr2 only in certain populations of neurons is possible by crossing floxed $\beta$ arr2 mice with D1Cre mice (for D1containing cells), D2Cre mice (for all D2-containing cells), A2aCre mice (for D2-containing postsynaptic striatal neurons), or ChaTCre mice (for cholinergic interneurons). Mice lacking $\beta$ arr2 in striatal D2 MSNs or in all D2-containing neurons but not in D1-containing neurons or cholinergic interneurons exhibited blunted amphetamine-induced locomotion (Urs et al., 2016). These experiments demonstrated that $\beta$ arr2 in D2-containing neurons, particularly in the striatum, facilitates amphetamine locomotor responses. To further probe the role of $\beta$ arr2 in behavioral responses to amphetamines, viral vectors have been created to express D2 receptors with biased G protein signaling or D2 receptors with biased $\beta$ Arr2 signaling. Overexpressing D2 receptors with biased $\beta$ arr2 but not G protein signaling in the striatum potentiated amphetamine-induced locomotion (Peterson et al., 2015), revealing a role of $\beta$ arr2 signaling downstream of striatal D2 receptors. Together, these experiments demonstrated that $\beta$ arr2 modulates the locomotoractivating effects of psychostimulants, likely through $\beta$ arr2 signaling in D2-containing cells. Future experiments should test whether this mechanism also mediates psychostimulant reward.

Mice that lack dopamine $\beta$-hydroxylase $(D b h-/-$ mice) cannot synthesize norepinephrine and are hypersensitive to cocaine. Interestingly, these animals had reduced $\beta$ arr2 in the nucleus accumbens and altered D2 receptor function (GavalCruz et al., 2016). Overexpressing $\beta$ arr2 in the nucleus accumbens of $D b h-/-$ mice reversed the cocaine hypersensitivity (Gaval-Cruz et al., 2016), demonstrating the complex effects that $\beta$ arr2 can have in cocaine-induced locomotion. These results are difficult to reconcile with the data obtained from $\beta$ arr2-KO mice, which show minimal or no blunting of cocaine-induced locomotion and significantly reduced amphetamine-induced locomotion, suggesting that overexpression of $\beta$ arr2 would potentiate, not reduce, cocaine-induced locomotion. One possible explanation is that $D b h-/-$ mice have unique neural adaptations due to their chronic, lifelong loss of norepinephrine. An alternative explanation is that $\beta$ arr2 in the nucleus accumbens functions in a bimodal way, such that abnormally high or low levels of $\beta$ arr2 could blunt psychostimulant responses. Finally, whether $D b h-/-$ mice have reduced $\beta$ arr2 in D1-, D2-, or both D1- and D2-containing MSNs is currently unknown, and the ratio of $\beta$ arr2 in these two cell populations could potentially influence cocaine-induced locomotion.

Alcohol. $\beta$ arr2-KO mice have been used to test the role of $\beta$ arr2 in alcohol reinforcement. Whereas one study found that mice completely lacking $\beta$ arr2 consumed significantly less alcohol at low doses and had a reduced preference for alcohol in a two-bottle choice procedure compared with controls (Björk et al., 2008), another laboratory observed that $\beta$ arr2-KO mice consumed more alcohol, especially at higher doses (Li et al., 2013). However, both studies reported that $\beta$ arr2-KO mice had enhanced CPP for low doses of alcohol (Björk et al., 2013; $\mathrm{Li}$ et al., 2013), possibly indicating that the lack of $\beta \mathrm{arr} 2$ conferred hypersensitivity to the rewarding properties of alcohol. $\beta$ arr2-KO mice also had attenuated alcohol-induced locomotor responses compared with wild-type animals (Björk et al., 2008; Li et al., 2013).

$\beta$ arr2-KO mice regained their righting reflex slightly faster than controls after a large dose of alcohol (Li et al., 2013) but 
had normal motor performance on a rotarod when under the influence of alcohol (Björk et al., 2008). In addition, although $\beta$ arr2-KO mice had slightly reduced blood alcohol levels after a single alcohol injection, alcohol clearance rates were similar to wild-type mice (Björk et al., 2008; Li et al., 2013). Combined, these experiments indicate that the differences in behavioral response of $\beta$ arr2-KO mice to alcohol probably cannot be attributed to differences in the sedative properties of ethanol or its pharmacokinetics.

A few studies have examined genetic differences in $\beta$ arr 2 in relation to alcohol. Two lines of rats, "alcohol-preferring" and "alcohol-avoiding," have been bred based on their voluntary alcohol intake. Alcohol-preferring rats had elevated levels of $\beta$ arr2 mRNA in the nucleus accumbens, dorsal striatum, and hippocampus, as well as higher $\beta$ arr2 protein in the hippocampus compared with alcohol-avoiding rats (Björk et al., 2008). Interestingly, Björk et al. (2008) uncovered a novel haplotype variant of the $\beta$ arr2 gene that completely segregated between the two lines of rats and was highly correlated with ethanol consumption, and bioinformatic analysis revealed an expression quantitative trait locus for $\beta$ arr2 in the brain regions that had elevated $\beta$ arr 2 mRNA. This is consistent with the observation that $\beta$ arr2-KO mice voluntarily consumed less alcohol (Björk et al., 2008). Higher levels of $\beta$ arr2 therefore predict greater ethanol consumption, whereas eliminating $\beta$ arr2 reduces ethanol intake. Although genetic differences in $\beta$ arr 2 correspond to ethanol intake in rodents, no association between different polymorphisms of $\beta$ arr 2 and alcohol dependence has been observed in humans (Oneda et al., 2010).

The reinforcing effects of alcohol are thought to be mediated by dopamine release in striatal regions as well as endogenous opioid systems. Consistent with this theory, $\beta$ arr2-KO mice had enhanced alcohol-evoked dopamine release in the nucleus accumbens shell (Björk et al., 2013), which may contribute to the alcohol hypersensitivity. However, $\beta$ arr2-KO mice lacked the alcohol-induced elevations in $c$-fos in the nucleus accumbens shell seen in control animals (Björk et al., 2008). Although $\mu$-opioid receptor binding and function did not differ between $\beta$ arr2-KO and wild-type mice in drug-naïve conditions (likely due to low levels of receptor activation), alcohol induced greater $\mu$-opioid receptor agonist stimulation in the dorsal striatum and amygdala of $\beta$ arr2-KO mice (Björk et al., 2013). These differences in $\mu$-opioid receptor function may contribute to the altered behavioral responses to alcohol in $\beta$ arr2-KO mice. The impaired desensitization and internalization of $\mu$-opioid receptors in the absence of $\beta$ arr 2 may cause heightened $\mu$-opioid receptor signaling and greater sensitivity to alcohol, as evidenced by enhanced CPP and reduced ethanol intake.

In addition to $\mu$-opioid receptors, $\delta$-opioid receptors can also interact with $\beta$ arr2 and modulate alcohol intake. $\delta$-opioid receptor agonists that strongly recruit $\beta$ arr2 have been shown to increase ethanol intake in wild-type mice, whereas agonists with poor $\beta$ arr2 recruitment dose-dependently decreased ethanol consumption (Chiang et al., 2016). Furthermore, an agonist with low $\beta$ arr2 recruitment decreased ethanol intake in $\beta$ arr2-KO mice, whereas an agonist that robustly recruits $\beta$ arr2 neither decreased ethanol intake nor blocked the development of a CPP for alcohol in $\beta$ arr2-KO mice (Chiang et al., 2016). These results indicated that the effect of low $\beta$ arr2-recruiting $\delta$-opioid receptor agonists to decrease alcohol consumption occurs through $\beta$ arr2-independent mechanisms, whereas high $\beta$ Arr2-recruiting $\delta$-opioid agonists require $\beta$ arr 2 to enhance alcohol intake. Together, this series of experiments demonstrates that the ability of ${ }_{\Delta}$-opioid receptor agonists to recruit $\beta$ arr2 has significant effects on alcohol intake. Examining $\beta$ arr 2 recruitment of different $\delta$-opioid agonists is critical because these compounds are being considered as treatments for alcoholism and depression, and giving a high $\beta$ arr2-recruiting $\delta$-opioid agonist could potentially exacerbate alcoholism rather than attenuate it.

Nicotine. Very few published studies have examined the influence of $\beta$ arr2 on nicotine responses. In adolescent mice, nicotine caused hypolocomotion in both wild-type and $\beta$ arr2-KO animals, and $\beta$ arr2-KO mice appeared to be more sensitive to this effect (Correll et al., 2009). However, as previously noted, genotype differences in baseline locomotor activity make these results difficult to interpret. $\beta$ arr2-KO mice also exhibited impaired nicotine-induced locomotor sensitization; whereas repeated nicotine administration significantly increased locomotion in adolescent control mice, adolescent nicotine-induced locomotor activity was stable over time in $\beta$ arr2-KO mice (Correll et al., 2009). Future experiments are needed to determine whether these $\beta$ arr2-associated changes in locomotor activity are also reflected in nicotine reward.

As with opioid-dependent individuals, certain polymorphisms of $\beta$ arr2 have been associated with nicotine users. In European Americans but not African Americans, the rs4790694 SNP of $\beta$ arr2 significantly correlated with the Heaviness of Smoking Index and the Fagerström Test for Nicotine Dependence (Sun et al., 2008). This finding demonstrated that particular polymorphisms of $\beta$ arr2 can confer risk of nicotine dependence in certain human populations. Further research is needed to determine the biologic effects of this polymorphism on $\beta$ arr2 function in neurons. To note, this is not one of the same SNPs that predicted drug relapse while on methadone maintenance therapy (Oneda et al., 2011).

Hallucinogens. Hallucinogenic effects are mediated by the serotonin (5-HT) system, particularly the 5- $\mathrm{HT}_{2 \mathrm{~A}}$ receptor. Studying hallucinations in rodents is difficult due to the cognitive nature of hallucinations; however, rodents treated with hallucinogens exhibit a head twitch that can be quantified, and $\beta$ arr2 is involved in this behavioral response. Unlike control mice, $\beta$ arr2-KO mice did not exhibit a head twitch response to moderate doses of the 5-HT precursor 5-HTP; however, $\beta$ arr2-KOs displayed a normal head twitch to the $5-\mathrm{HT}_{2 \mathrm{~A}}$ receptor agonist 2,5-dimethoxy-4-iodoamphetamine, and had more head twitches than wild-type mice at high doses of 5-HTP (Schmid et al., 2008; Schmid and Bohn, 2010). In addition, 5 -HT, but not $N$-methyltraptamines, engaged a $\beta$ arr2/ phosphoinositide 3-kinase/Src/Akt cascade in cortical neurons (Schmid and Bohn, 2010). Together, these experiments indicate that both $N$-methyltraptamines and 5-HT induce head twitch via the $5-\mathrm{HT}_{2 \mathrm{~A}}$ receptor, but do so through different mechanisms. $\beta$ arr 2 promotes the 5 -HT-induced response but attenuates the $N$-methyltryptamine-induced response (Schmid and Bohn, 2010). These experiments highlight the importance of functional selectivity of different agonists at the same receptor.

Similar to other hallucinogens, the effects of lysergic acid diethylamide (LSD) are primarily mediated by the serotonin $5-\mathrm{HT}_{2 \mathrm{~A}}$ receptor (De Gregorio et al., 2016), although LSD binds to most serotonin receptors and some other GPCRs (Kroeze et al., 2015). A few studies have used the $5-\mathrm{HT}_{2 \mathrm{~B}}$ 
receptor, which is very similar to the $5-\mathrm{HT}_{2 \mathrm{~A}}$ receptor, to study the molecular effects of LSD. Compared with 5-HT and other agonists, LSD is strongly biased toward $\beta$ arr2 signaling over G protein signaling at the $5-\mathrm{HT}_{2 \mathrm{~B}}$ receptor (Wacker et al., 2013), which may contribute to its hallucinogenic effects (Chen and Tesmer, 2017). Recently, the crystal structure of LSD bound to the $5-\mathrm{HT}_{2 \mathrm{~B}}$ receptor was described, and $5-\mathrm{HT}_{2 \mathrm{~A}}$ receptor models show similar binding properties. Interestingly, a portion of an extracellular loop of the receptor (EL2) formed a "lid" over LSD, which prevented LSD from dissociating from the receptor and may be responsible for LSD's long duration of action. Indeed, mutating part of the lid (L209 ${ }^{\mathrm{EL} 2}$ ) resulted in a 10-fold reduction in the duration of time that LSD was bound to the receptor. In addition, this mutation significantly decreased LSD's recruitment of $\beta$ arr2 without altering Gq-mediated calcium flux (Wacker et al., 2017). These results indicate that LSD recruits $\beta$ arr2, and future experiments should examine the behavioral consequences of $\beta$ arr2 in the hallucinogenic effects of LSD.

A few experiments have examined $\beta$ arr2's role in phencyclidine (PCP) effects in the context of schizophrenia, because PCP can induce psychotic-like effects (Urs et al., 2017). PCP robustly increased locomotor activity in wild-type and $\beta$ arr2-KO mice (Allen et al., 2011). $\beta$ arr2-biased D2 receptor agonists, such as UNC9994 (5-\{3-[4-(2,3-dichlorophenyl)piperidin-1-yl]propoxy\}-1,3-benzothiazole) [also known as UNC9994A], have been developed and have antipsychoticlike properties. UNC9994 attenuated PCP-induced locomotion in wild-type mice but had no effect in $\beta$ arr2-KO mice, demonstrating functional selectivity of the ligand (Allen et al., 2011). Injecting UNC9994A into the mouse prefrontal cortex inhibited PCP-induced locomotion, and eliminating $\beta$ arr2 in D2-containing neurons prevented this effect. $\beta$ arr2 in nonstriatal D2 neurons, such as the cortex, likely mediates PCP-induced locomotion because eliminating $\beta$ arr2 only in D2-containing striatal neurons did not alter the ability of UNC9994A to inhibit PCP-induced locomotion, but virally removing $\beta$ arr2 in cortical D2 neurons abolished the drug's effect (Urs et al., 2016). In addition to functional selectivity, UNC9994A caused different effects in D2 receptor-containing neurons in the striatum versus the prefrontal cortex. Whereas UNC9994A did not affect the excitability of striatal MSNs, UNC9994A increased fast-spiking interneuron excitability in the prefrontal cortex, and this effect was mediated by elevated GRK2 expression (Urs et al., 2016). The finding that a biased $\beta$ arr2 ligand at D2 receptors functions as an agonist in the prefrontal cortex but not in the striatum demonstrates the importance of the brain region-specific properties of $\beta$ arr2.

\section{Summary}

In summary, most rodent experiments examining the contribution of $\beta$ arr2 to the effects of addictive drugs have used conventional $\beta$ arr2-KOs. Completely eliminating $\beta$ arr2 causes changes in the behavioral responses to most classes of drugs of abuse, but whether it blunts, potentiates, or has no effect varies by assay (drug-induced locomotion versus $\mathrm{CPP}$ ) and drug (Table 1). In the instances where complete loss of $\beta$ arr2 has no significant reported effects, such as with cocaine, there are a few potential explanations: $\beta$ arr2 could be uninvolved, $\beta$ arr1 could be compensating for the lack of $\beta$ arr2, and/or the assays used lacked sufficient sensitivity to detect a $\beta$ arr2-KO phenotype. Wholebody deletion of $\beta$ arr2 typically blunts opioid, psychostimulant, nicotine, and ethanol-induced locomotion; however, loss of $\beta$ arr2 can potentiate opioid and alcohol reward. Together, these findings indicate that $\beta$ arr2 is differentially involved in the rewarding versus locomotor-activating effects of drugs and support the notion that locomotor responses to drugs do not always reliably predict their rewarding properties.

The most thorough investigations of $\beta$ arr2's involvement in drug effects thus far have been conducted with morphine and amphetamine. $\beta$ arr2 signaling, particularly in D2-containing MSNs, mediates amphetamine-induced locomotion (Peterson et al., 2015; Urs et al., 2016); however, whether this mechanism also mediates amphetamine reward is currently unknown. By contrast, $\beta$ arr2 in D1-containing neurons is proposed to mediate morphine-induced locomotion but not reward (Urs et al., 2011; Urs and Caron, 2014). While a simplistic model whereby $\beta$ arr2 mediates all psychomotor drug effects would be convenient, the data indicate that $\beta$ arr2 is likely modulating different drug effects in different brain regions through interactions with various GPCRs and intracellular molecules. Much work remains to be done to elucidate how $\beta$ Arr2 modulates the behavioral effects of addictive drugs.

\section{Technical Advances and Limitations}

$\beta$ arr2-KO mice have been a valuable tool for testing the global effects of $\beta$ arr2. As discussed earlier, however, genetic deletion carries the caveat that adaptations during development may mask, enhance, or otherwise alter $\beta$ arr2-associated phenotypes. In addition, $\beta$ arr2-KO mice obscure regional, cell type, and receptor-specific effects. Conditional knockouts whereby Barr2 is eliminated in D1- or D2-contianing cells by crossing floxed Barr2 mice with D1Cre or D2Cre mice (Urs et al., 2016) provide enhanced cell-type specificity but still lack regional specificity because $\mathrm{D} 1$ and $\mathrm{D} 2$ receptors are expressed in multiple brain regions. The floxed $\beta$ arr2/A2aCre mice, which lack $\beta$ arr2 in D2containing MSNs (Urs et al., 2016), provide enhanced regional and cell-type specificity but do not differentiate between subregions of the striatum, which can have different roles in addictive-like behaviors (Everitt and Robbins, 2013). Depending on the promoter, viral elimination or overexpression of $\beta$ arr2 can grant further regional and cell type specificity. Experiments using these techniques have focused primarily on knocking out $\beta$ arr2 (Urs et al., 2016), but using viral vectors to overexpress $\beta$ arr2 is also possible (Gaval-Cruz et al., 2016).

Viral vectors that express GPCRs with biased $\beta$ arr2 signaling (Peterson et al., 2015) are a useful tool for dissociating the effects of receptor activation and engagement of multiple signaling pathways with the specific effects of $\beta$ arr2 in the cells containing that receptor. D2 receptors that preferentially activate $\beta$ arr2 signaling or traditional Gi/o signaling can be used to dissect the importance of one pathway over the other (Peterson et al., 2015) and are useful for testing the in vivo effects of D2 receptor-mediated activation of each pathway. Developing mutated D1, $\mu$-opioid, and cannabinoid receptors that preferentially induce $\mathrm{G}$ protein or $\beta$ arr2 signaling would also be beneficial for future experiments examining the role of $\beta$ arr2 in drug effects. The limitation of biased signaling experiments is that they currently require viral infusions that typically result in overexpression of the GPCRs, which may or may not reflect natural $\beta$ arr2 signaling and function.

Although direct agonists/antagonists of $\beta$ arr2 are not yet available, biased ligands that are receptor agonists preferentially 
engaging $\beta$ arr2 are useful tools for eliciting $\beta$ arr2 signaling versus canonical $G$ protein signaling. For example, there are D2 receptor ligands that function as partial agonists engaging $\beta$ arr2 but not G protein signaling (Allen et al., 2011), and there are $\kappa$-opioid receptor agonists that harness $\mathrm{G}$ protein but not $\beta$ arr signaling (Rives et al., 2012). Additional drugs that specifically and acutely target $\beta$ Arr 2 would be beneficial to more thoroughly investigate the role of this protein in modulating behavioral responses to drugs of abuse.

Designer receptors exclusively activated by designer drugs (DREADDs), which use mutated receptors with selective ligands to activate or inactivate particular cells or signaling pathways, have become a popular tool in neuroscience research recently (Roth, 2016; Smith et al., 2016). A DREADD has been invented that activates $\beta$ arrs but not $G$ proteins (Nakajima et al., 2015), which could be very useful for preferentially activating $\beta$ arrs without causing signaling from endogenous receptors. To our knowledge, this $\beta$ arr DREADD has not yet been employed to investigate $\beta$ arr 2 contributions to behavior or in relation to drugs of abuse.

Another limitation in studying $\beta$ arr2 is the difficulty in visualizing the protein. Immunohistochemistry and western blot experiments have suffered from a lack of commercially available, sensitive, and specific $\beta$ arr2 antibodies. Some investigator-produced antibodies have yielded better results (Urs et al., 2016), but these resources are limited. Recently, $\beta$ arr2 biosensors have been developed to detect in vitro realtime conformational changes in $\beta$ arr2 and the "megaplexes" that can form combining internalized GPCR, $\beta$ arr2, and G protein (Nuber et al., 2016). These sensors could be useful in visualizing the precise conformational changes and intracellular movements of $\beta$ arr2 in response to drugs of abuse.

Surprisingly, only a few experiments to date have used electrophysiology to examine how $\beta$ arr2 manipulations affect the excitability of neurons within reward circuits. Enkephalin hyperpolarized locus coeruleus neurons to the same degree in $\beta$ arr2-KO and control neurons (Arttamangkul et al., 2008). Interestingly, the $\beta$ arr2-biased D2 ligand UNC9994A had little effect on striatal MSNs but increased the excitability of fast-spiking interneurons in the prefrontal cortex. This increased activity in the cortex was attenuated in $\beta$ arr2-KOs, indicating that $\beta$ arr2 mediates the effects of UNC9994A on cell excitability (Urs et al., 2016). In addition, whereas the D2 agonist quinpirole normally decreases the excitability of MSNs, it increased the excitability of MSNs in Dbh - / - mice that have decreased $\beta$ arr2 in the nucleus accumbens (GavalCruz et al., 2016). These experiments hint at the complex effects that $\beta$ arr 2 can have on neural activity in different brain regions. Future experiments should investigate psychostimulantand opioid-induced changes in the excitability of D1- and D2containing MSNs and prefrontal cortical neurons after $\beta$ arr2 manipulations. Additionally, $\beta$ arr2's role in synaptic plasticity after drug use should be examined.

Because the defining symptoms of drug abuse are behavioral, biologic targets for treating drug abuse must be able to change either the reinforcing properties of drugs or the motivation to take drugs. Most experiments examining the behavioral effects of $\beta$ arr 2 manipulations have used simple behavioral procedures, such as drug-induced locomotion, locomotor sensitization, or CPP. These behavioral tasks are useful screens for measuring drug responses because they are reliable, technically simple, inexpensive, and quantitative; however, on their own, they are inadequate assays for addiction. Future studies should use operant drug self-administration procedures that can answer more sophisticated behavioral questions probing voluntary intake, escalation of intake, drug consumption despite adverse consequences, and relapse-like behavior.

\section{Acknowledgments}

The authors thank C. Strauss for helpful editing of the manuscript.

\section{Authorship Contributions}

Wrote or contributed to the writing of the manuscript: PorterStransky, Weinshenker.

\section{References}

Ahn S, Wei H, Garrison TR, and Lefkowitz RJ (2004) Reciprocal regulation of angiotensin receptor-activated extracellular signal-regulated kinases by betaarrestins 1 and 2. $J$ Biol Chem 279:7807-7811.

Allen JA, Yost JM, Setola V, Chen X, Sassano MF, Chen M, Peterson S, Yadav PN, Huang XP, Feng B, et al. (2011) Discovery of $\beta$-arrestin-biased dopamine D2 ligands for probing signal transduction pathways essential for antipsychotic efficacy. Proc Natl Acad Sci USA 108:18488-18493.

Arttamangkul S, Quillinan N, Low MJ, von Zastrow M, Pintar J, and Williams JT (2008) Differential activation and trafficking of micro-opioid receptors in brain slices. Mol Pharmacol 74:972-979.

Attramadal H, Arriza JL, Aoki C, Dawson TM, Codina J, Kwatra MM, Snyder SH, Caron MG, and Lefkowitz RJ (1992) Beta-arrestin2, a novel member of the arrestin/beta-arrestin gene family. J Biol Chem 267:17882-17890.

Atwood BK, Wager-Miller J, Haskins C, Straiker A, and Mackie K (2012) Functional selectivity in $\mathrm{CB}(2)$ cannabinoid receptor signaling and regulation: implications for the therapeutic potential of $\mathrm{CB}(2)$ ligands. Mol Pharmacol 81:250-263.

Beaulieu JM and Gainetdinov RR (2011) The physiology, signaling, and pharmacology of dopamine receptors. Pharmacol Rev 63:182-217.

Beaulieu JM, Sotnikova TD, Marion S, Lefkowitz RJ, Gainetdinov RR, and Caron MG (2005) An Akt/beta-arrestin 2/PP2A signaling complex mediates dopaminergic neurotransmission and behavior. Cell 122:261-273.

Berger AC and Whistler JL (2011) Morphine-induced mu opioid receptor trafficking enhances reward yet prevents compulsive drug use. EMBO Mol Med 3:385-397.

Björk K, Rimondini R, Hansson AC, Terasmaa A, Hyytiä P, Heilig M, and Sommer WH (2008) Modulation of voluntary ethanol consumption by beta-arrestin 2 . FASEB J 22:2552-2560.

Björk K, Tronci V, Thorsell A, Tanda G, Hirth N, Heilig M, Hansson AC, and Sommer WH (2013) $\beta$-arrestin 2 knockout mice exhibit sensitized dopamine release and increased reward in response to a low dose of alcohol. Psychopharmacology (Berl) 230:439-449.

Boerrigter G, Soergel DG, Violin JD, Lark MW, and Burnett JC, Jr (2012) TRV120027, a novel $\beta$-arrestin biased ligand at the angiotensin II type I receptor, unloads the heart and maintains renal function when added to furosemide in experimental heart failure. Circ Heart Fail 5:627-634.

Bohn LM, Dykstra LA, Lefkowitz RJ, Caron MG, and Barak LS (2004a) Relative opioid efficacy is determined by the complements of the $\mathrm{G}$ protein-coupled receptor desensitization machinery. Mol Pharmacol 66:106-112.

Bohn LM, Gainetdinov RR, and Caron MG (2004b) G protein-coupled receptor kinase/ $\beta$-arrestin systems and drugs of abuse: psychostimulant and opiate studies in knockout mice. Neuromolecular Med 5:41-50.

Bohn LM, Gainetdinov RR, Sotnikova TD, Medvedev IO, Lefkowitz RJ, Dykstra LA, and Caron MG (2003) Enhanced rewarding properties of morphine, but not cocaine, in $\beta$ (arrestin)-2 knock-out mice. J Neurosci 23:10265-10273.

Bohn LM, Lefkowitz RJ, and Caron MG (2002) Differential mechanisms of morphine antinociceptive tolerance revealed in (beta)arrestin-2 knock-out mice. J Neurosci 22:10494-10500.

Bohn LM, Lefkowitz RJ, Gainetdinov RR, Peppel K, Caron MG, and Lin FT (1999) Enhanced morphine analgesia in mice lacking beta-arrestin 2. Science 286: 2495-2498.

Breivogel CS, Lambert JM, Gerfin S, Huffman JW, and Razdan RK (2008) Sensitivity to delta9-tetrahydrocannabinol is selectively enhanced in beta-arrestin2 -/- mice. Behav Pharmacol 19:298-307.

Chen Q and Tesmer JJ (2017) A receptor on acid. Cell 168:339-341.

Chiang T, Sansuk K, and van Rijn RM (2016) $\beta$-arrestin 2 dependence of $\delta$ opioid receptor agonists is correlated with alcohol intake. $\mathrm{Br}$ J Pharmacol 173:332-343.

Correll JA, Noel DM, Sheppard AB, Thompson KN, Li Y, Yin D, and Brown RW (2009) Nicotine sensitization and analysis of brain-derived neurotrophic factor in adolescent beta-arrestin-2 knockout mice. Synapse 63:510-519.

Daigle TL, Kearn CS, and Mackie K (2008) Rapid CB1 cannabinoid receptor desensitization defines the time course of ERK1/2 MAP kinase signaling. Neuropharmacology 54:36-44.

De Gregorio D, Comai S, Posa L, and Gobbi G (2016) d-Lysergic acid diethylamide (LSD) as a model of psychosis: mechanism of action and pharmacology. Int J Mol Sci 17:1953.

Del'guidice T, Lemasson M, and Beaulieu JM (2011) Role of beta-arrestin 2 downstream of dopamine receptors in the basal ganglia. Front Neuroanat 5:58.

Delgado-Peraza F, Ahn KH, Nogueras-Ortiz C, Mungrue IN, Mackie K, Kendall DA, and Yudowski GA (2016) Mechanisms of biased $\beta$-arrestin-mediated signaling downstream from the cannabinoid 1 receptor. Mol Pharmacol 89:618-629. 
Di Chiara G and Imperato A (1988) Drugs abused by humans preferentially increase synaptic dopamine concentrations in the mesolimbic system of freely moving rats. Proc Natl Acad Sci USA 85:5274-5278.

Dolph PJ (2002) Arrestin: roles in the life and death of retinal neurons. Neuroscientist 8:347-355.

Everitt BJ and Robbins TW (2013) From the ventral to the dorsal striatum: devolving views of their roles in drug addiction. Neurosci Biobehav Rev 37:1946-1954.

Fan XL, Zhang JS, Zhang XQ, Yue W, and Ma L (2003) Differential regulation of $\beta$-arrestin 1 and $\beta$-arrestin 2 gene expression in rat brain by morphine. Neuroscience 117:383-389.

Ferrer-Alcón M, La Harpe R, and García-Sevilla JA (2004) Decreased immunodensities of micro-opioid receptors, receptor kinases GRK $2 / 6$ and beta-arrestin-2 in postmortem brains of opiate addicts. Brain Res Mol Brain Res 121:114-122.

Finn AK and Whistler JL (2001) Endocytosis of the mu opioid receptor reduces tolerance and a cellular hallmark of opiate withdrawal. Neuron 32:829-839.

Franklin JM, Vasiljevik T, Prisinzano TE, and Carrasco GA (2013) Cannabinoid agonists increase the interaction between $\beta$-arrestin 2 and ERK1/2 and upregulate $\beta$-arrestin 2 and 5-HT(2A) receptors. Pharmacol Res 68:46-58.

Gao H, Sun Y, Wu Y, Luan B, Wang Y, Qu B, and Pei G (2004) Identification of $\beta$-arrestin2 as a $\mathrm{G}$ protein-coupled receptor-stimulated regulator of NF-kappaB pathways. Mol Cell 14:303-317.

Gaval-Cruz M, Goertz RB, Puttick DJ, Bowles DE, Meyer RC, Hall RA, Ko D, Paladini CA, and Weinshenker D (2016) Chronic loss of noradrenergic tone produces $\beta$-arrestin2-mediated cocaine hypersensitivity and alters cellular D2 responses in the nucleus accumbens. Addict Biol 21:35-48.

Groer CE, Schmid CL, Jaeger AM, and Bohn LM (2011) Agonist-directed interactions with specific $\beta$-arrestins determine $\mu$-opioid receptor trafficking, ubiquitination, and dephosphorylation. J Biol Chem 286:31731-31741.

Gurevich VV and Gurevich EV (2004) The molecular acrobatics of arrestin activation. Trends Pharmacol Sci 25:105-111.

Haberstock-Debic H, Kim KA, Yu YJ, and von Zastrow M (2005) Morphine promotes rapid, arrestin-dependent endocytosis of $\mu$-opioid receptors in striatal neurons. $J$ Neurosci 25:7847-7857.

Irannejad R, Tomshine JC, Tomshine JR, Chevalier M, Mahoney JP, Steyaert J, Rasmussen SG, Sunahara RK, El-Samad H, Huang B, et al. (2013) Conformational biosensors reveal GPCR signalling from endosomes. Nature 495:534-538.

Keith DE, Anton B, Murray SR, Zaki PA, Chu PC, Lissin DV, Monteillet-Agius G, Stewart PL, Evans CJ, and von Zastrow M (1998) mu-Opioid receptor internalization: opiate drugs have differential effects on a conserved endocytic mechanism in vitro and in the mammalian brain. Mol Pharmacol 53:377-384.

Kravitz AV, Tye LD, and Kreitzer AC (2012) Distinct roles for direct and indirect pathway striatal neurons in reinforcement. Nat Neurosci 15:816-818.

Kroeze WK, Sassano MF, Huang X-P, Lansu K, McCorvy JD, Giguère PM, Sciaky N, and Roth BL (2015) PRESTO-Tango as an open-source resource for interrogation of the druggable human GPCRome. Nat Struct Mol Biol 22:362-369.

Kuhar JR, Bedini A, Melief EJ, Chiu YC, Striegel HN, and Chavkin C (2015) Mu opioid receptor stimulation activates c-Jun $\mathrm{N}$-terminal kinase 2 by distinct arrestin-dependent and independent mechanisms. Cell Signal 27:1799-1806.

Lee HJ, Weitz AJ, Bernal-Casas D, Duffy BA, Choy M, Kravitz AV, Kreitzer AC, and Lee $\mathrm{JH}$ (2016) Activation of direct and indirect pathway medium spiny neurons drives distinct brain-wide responses. Neuron 91:412-424

Li H, Tao Y, Ma L, Liu X, and Ma L (2013) $\beta$-arrestin-2 inhibits preference for alcohol in mice and suppresses Akt signaling in the dorsal striatum. Neurosci Bull 29:531-540.

Lobo MK and Nestler EJ (2011) The striatal balancing act in drug addiction: distinct roles of direct and indirect pathway medium spiny neurons. Front Neuroanat 5:41.

Lüscher C and Ungless MA (2006) The mechanistic classification of addictive drugs. PLoS Med 3:e437.

Luttrell LM, Maudsley S, and Bohn LM (2015) Fulfilling the promise of "biased" G protein-coupled receptor agonism. Mol Pharmacol 88:579-588.

Luttrell LM, Roudabush FL, Choy EW, Miller WE, Field ME, Pierce KL, and Lefkowitz RJ (2001) Activation and targeting of extracellular signal-regulated kinases by $\beta$-arrestin scaffolds. Proc Natl Acad Sci USA 98:2449-2454.

Mahavadi S, Sriwai W, Huang J, Grider JR, and Murthy KS (2014) Inhibitory signaling by CB1 receptors in smooth muscle mediated by GRK5/ 3 -arrestin activation of ERK1/ 2 and Src kinase. Am J Physiol Gastrointest Liver Physiol 306:G535-G545.

Manglik A, Lin H, Aryal DK, McCorvy JD, Dengler D, Corder G, Levit A, Kling RC, Bernat V, Hübner H, et al. (2016) Structure-based discovery of opioid analgesics with reduced side effects. Nature 537:185-190.

McGuinness D, Malikzay A, Visconti R, Lin K, Bayne M, Monsma F, and Lunn CA (2009) Characterizing cannabinoid CB2 receptor ligands using DiscoveRx PathHunter beta-arrestin assay. J Biomol Screen 14:49-58.

Nakajima K, Gimenez LED, Gurevich VV, and Wess J (2015) Design and analysis of an arrestin-biased DREADD. Designer Receptors Exclusively Activated by Designer Drugs (Thiel G ed) vol 108, pp 29-48, Springer, New York.

Nguyen PT, Schmid CL, Raehal KM, Selley DE, Bohn LM, and Sim-Selley LJ (2012) $\beta$-arrestin2 regulates cannabinoid CB1 receptor signaling and adaptation in a central nervous system region-dependent manner. Biol Psychiatry 71:714-724.

Nuber S, Zabel U, Lorenz K, Nuber A, Milligan G, Tobin AB, Lohse MJ, and Hoffmann $\mathrm{C}$ (2016) $\beta$-arrestin biosensors reveal a rapid, receptor-dependent activation/deactivation cycle. Nature 531:661-664.

Oakley RH, Laporte SA, Holt JA, Caron MG, and Barak LS (2000) Differential affinities of visual arrestin, $\beta$ arrestin1, and $\beta$ arrestin2 for $G$ protein-coupled receptors delineate two major classes of receptors. J Biol Chem 275:17201-17210.

Oneda B, Crettol S, Bochud M, Besson J, Croquette-Krokar M, Hämmig R, Monnat M, Preisig M, and Eap CB (2011) $\beta$-arrestin2 influences the response to methadone in opioid-dependent patients. Pharmacogenomics J 11:258-266.

Oneda B, Preisig M, Dobrinas M, and Eap CB (2010) Lack of association between genetic polymorphisms of ARRB2 and alcohol dependence in a Caucasian population. Alcohol Alcohol 45:590-591.
Peterson SM, Pack TF, Wilkins AD, Urs NM, Urban DJ, Bass CE, Lichtarge O, and Caron MG (2015) Elucidation of G-protein and $\beta$-arrestin functional selectivity at the dopamine D2 receptor. Proc Natl Acad Sci USA 112:7097-7102.

Pierce RC and Kumaresan V (2006) The mesolimbic dopamine system: the final common pathway for the reinforcing effect of drugs of abuse? Neurosci Biobehav Rev 30:215-238.

Raehal KM and Bohn LM (2011) The role of beta-arrestin2 in the severity of antinociceptive tolerance and physical dependence induced by different opioid pain therapeutics. Neuropharmacology 60:58-65.

Raehal KM and Bohn LM (2014) $\beta$-arrestins: regulatory role and therapeutic potential in opioid and cannabinoid receptor-mediated analgesia. Handb Exp Pharmacol 219:427-443.

Raehal KM, Walker JKL, and Bohn LM (2005) Morphine side effects in beta-arrestin 2 knockout mice. J Pharmacol Exp Ther 314:1195-1201.

Rives ML, Rossillo M, Liu-Chen L-Y, and Javitch JA (2012) 6'-Guanidinonaltrindole $\left(6^{\prime}\right.$-GNTI) is a G protein-biased $\kappa$-opioid receptor agonist that inhibits arrestin recruitment. J Biol Chem 287:27050-27054.

Roth BL (2016) DREADDs for neuroscientists. Neuron 89:683-694.

Schmid CL and Bohn LM (2010) Serotonin, but not N-methyltryptamines, activates the serotonin $2 \mathrm{~A}$ receptor via a $\beta$-arrestin2/Src/Akt signaling complex in vivo. $J$ Neurosci 30:13513-13524.

Schmid CL, Raehal KM, and Bohn LM (2008) Agonist-directed signaling of the serotonin 2A receptor depends on beta-arrestin-2 interactions in vivo. Proc Natl Acad Sci USA 105:1079-1084.

Schmitt KC and Reith ME (2010) Regulation of the dopamine transporter: aspects relevant to psychostimulant drugs of abuse. Ann N Y Acad Sci 1187:316-340.

Shenoy SK, Drake MT, Nelson CD, Houtz DA, Xiao K, Madabushi S, Reiter E, Premont RT, Lichtarge O, and Lefkowitz RJ (2006) Beta-arrestin-dependent, G protein-independent ERK1/2 activation by the beta2 adrenergic receptor. $J$ Biol Chem 281:1261-1273.

Shenoy SK, McDonald PH, Kohout TA, and Lefkowitz RJ (2001) Regulation of receptor fate by ubiquitination of activated $\beta 2$-adrenergic receptor and $\beta$-arrestin. Science 294:1307-1313.

Smith JS and Rajagopal S (2016) The $\beta$-arrestins: multifunctional regulators of G protein-coupled receptors. J Biol Chem 291:8969-8977.

Smith KS, Bucci DJ, Luikart BW, and Mahler SV (2016) DREADDS: use and application in behavioral neuroscience. Behav Neurosci 130:137-155.

Soergel DG, Subach RA, Burnham N, Lark MW, James IE, Sadler BM, Skobieranda F, Violin JD, and Webster LR (2014) Biased agonism of the $\mu$-opioid receptor by TRV130 increases analgesia and reduces on-target adverse effects versus morphine: A randomized, double-blind, placebo-controlled, crossover study in healthy volunteers. Pain 155:1829-1835.

Sun D, Ma JZ, Payne TJ, and Li MD (2008) Beta-arrestins 1 and 2 are associated with nicotine dependence in European American smokers. Mol Psychiatry 13:398-406.

Tarigopula M, Davis RT, 3rd, Mungai PT, Ryba DM, Wieczorek DF, Cowan CL, Violin JD, Wolska BM, and Solaro RJ (2015) Cardiac myosin light chain phosphorylation and inotropic effects of a biased ligand, TRV120023, in a dilated cardiomyopathy model. Cardiovasc Res 107:226-234.

Turu G and Hunyady L (2010) Signal transduction of the CB1 cannabinoid receptor. $J$ Mol Endocrinol 44:75-85.

Urs NM and Caron MG (2014) The physiological relevance of functional selectivity in dopamine signalling. Int J Obes Suppl 4 (Suppl 1):S5-S8.

Urs NM, Daigle TL, and Caron MG (2011) A dopamine D1 receptor-dependent $\beta$-arrestin signaling complex potentially regulates morphine-induced psychomotor activation but not reward in mice. Neuropsychopharmacology $\mathbf{3 6}$ $551-558$

Urs NM, Gee SM, Pack TF, McCorvy JD, Evron T, Snyder JC, Yang X, Rodriguiz RM, Borrelli E, Wetsel WC, et al. (2016) Distinct cortical and striatal actions of a $\beta$-arrestin-biased dopamine D2 receptor ligand reveal unique antipsychotic-like properties. Proc Natl Acad Sci USA 113:E8178-E8186.

Urs NM, Peterson SM, and Caron MG (2017) New concepts in dopamine D2 receptor biased signaling and implications for schizophrenia therapy. Biol Psychiatry 81: $78-85$.

van der Lee MMC, Blomenröhr M, van der Doelen AA, Wat JWY, Smits N, Hanson BJ, van Koppen CJ, and Zaman GJR (2009) Pharmacological characterization of receptor redistribution and beta-arrestin recruitment assays for the cannabinoid receptor 1. J Biomol Screen 14:811-823.

Wacker D, Wang C, Katritch V, Han GW, Huang XP, Vardy E, McCorvy JD, Jiang Y, Chu M, Siu FY, et al. (2013) Structural features for functional selectivity at serotonin receptors. Science 340:615-619.

Wacker D, Wang S, McCorvy JD, Betz RM, Venkatakrishnan A, Levit A, Lansu K Schools ZL, Che T, and Nichols DE (2017) Crystal structure of an LSD-bound human serotonin receptor. Cell 168:377-389.

Wehbi VL, Stevenson HP, Feinstein TN, Calero G, Romero G, and Vilardaga J-P

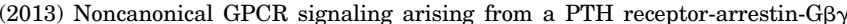
complex. Proc Natl Acad Sci USA 110:1530-1535.

Whistler JL and von Zastrow M (1998) Morphine-activated opioid receptors elude desensitization by beta-arrestin. Proc Natl Acad Sci USA 95:9914-9919.

Zhang J, Ferguson SSG, Barak LS, Bodduluri SR, Laporte SA, Law PY, and Caron MG (1998) Role for G protein-coupled receptor kinase in agonist-specific regulation of mu-opioid receptor responsiveness. Proc Natl Acad Sci USA 95: $7157-7162$.

Address correspondence to: Dr. David Weinshenker, Department of Human Genetics, Emory University School of Medicine, 615 Michael Street, Whitehead 301, Atlanta, GA 30322. E-mail: dweinshenker@genetics.emory. edu 